\title{
Microbial Diversity of a Remote Aviation Fuel Contaminated Sediment of a Lentic Ecosystem in Ibeno, Nigeria
}

\section{Udotong $\mathrm{IR}^{1 *}$, Uko MP ${ }^{1}$ and Udotong $\mathrm{JIR}^{2}$}

${ }^{1}$ Department of Microbiology, University of Uyo, Uyo, Akwa Ibom State, Nigeria

${ }^{2}$ Department of Biochemistry, University of Uyo, Uyo, Akwa Ibom State, Nigeria

\begin{abstract}
Environmental pollution from Oil \& Gas Exploration \& Production (O\&G E\&P) activities remains one of the major problems in the oil-producing communities of Nigeria. This results from improper oily wastes disposal as well as incessant oil spills in the region. The operator's lack of responsible business practices in wastes management and the over-dependence of the economy on oil and gas earnings, in the most part, exacerbate the problems of environmental pollution. Government's lack of political will power which treats issues on oil pollution with levity and long period of neglect of these polluted sites leave the environment ecologically destabilized. Studies to ascertain the ecological status of remote aviation fuel-contaminated sediment of a lentic ecosystem in Inua Eyet Ikot village, Ibeno, Nigeria, have been carried out using conventional microbiological culture-dependent methods. This methodology is known to reveal only $<1 \%$ of the microbial diversity present. These results were therefore considered inaccurate and grossly misleading. In this present study, sediment samples from this lentic ecosystem in Ibeno, Nigeria previously polluted by Aviation fuel in 2001 (about 14 years ago) were collected and analyzed to assess its prokaryotic diversity using both the conventional culture-dependent as well as culture-independent (16S metagenomic) techniques involving community DNA extraction, DNA sequencing and bioinformatics analyses. The culture-dependent techniques revealed the presence of only six genera of bacteria and no archaea was detected. The $16 \mathrm{~S}$ metagenomic methods revealed that the sediment of the polluted lentic ecosystem harbors a much more diverse population of bacteria and archaea. These results corroborate the 'great plate count anomaly' principle and demonstrate that the use of $16 \mathrm{~S}$ metagenomic tools will redefine the actual ecological status of the environment.
\end{abstract}

Keywords: Aviation fuel polluted site; Bioinformatics analyses; Community DNA extraction; Culture-dependent techniques; DNA sequencing; Lentic ecosystem; Prokaryotic diversity

\section{Introduction}

The Nigerian economy relies heavily on the revenue derived from the oil sector, as they provide $70 \%$ of government revenue and about $95 \%$ of foreign exchange earnings [1]. The nonchalant attitude of the oil operating companies in their improper ways of oily wastes disposal, intermittent oil spillages [2,3], relatively underdeveloped technology for spill prevention and response measures, and insufficient local capacity and political will power of government to stem the spate of incessant oil spill incidents in Nigeria [4], all result in increased risks of oil pollution and environmental degradation. Oil and gas reserves in Nigeria are concentrated in the Niger Delta region of the country, and have attracted the presence of multinational oil companies to the area $[5,6]$.

The Niger Delta region consists of nine states [7] with Akwa Ibom State as the highest oil-producing state and thus attracts the highest financial allocation from the federal government [8]. Ibeno Local Government Area hosts the operational base of Mobil Producing Nigeria Unlimited (MPNU), a subsidiary of Exxon Mobil and Qua Iboe Terminal (QIT) [9].

Thousands of barrels of oil have been spilt into the environment through oil pipelines bursts and oil tanker accidents in the country since the inception of oil activities, partly as a result of lack of regular maintenance of the oil installations e.g., pipelines replacements after they out-lived their installed lifespan and partly because of sabotage and other causes like oil tanker accidents. Notably, some of these facilities have been in use for decades without replacement [10]. For example, in 2004, an abandoned oil well at Oloibiri, Bayelsa State released about 20,000 barrels of oil into the environment [11] and evidence proved that the well had been leaking for many years without response from the operating company [12]. In January 1998, 40,000 barrels of crude oil from Idoho production platform of Exxon Mobil was spilt into the environment and caused severe damage to the entire Nigerian coastline [13]. Between 1997 and 2001, about 2,097 oil spill incidents were recorded in Nigeria [10]. Oil spill cases occur daily and in most cases more than once in a day in the Niger Delta region of Nigeria.

On 8th August 2001, Exxon Mobil's aviation fuel pipeline ruptured releasing about 1000 barrels of aviation fuel into a lentic ecosystem in Inua Eyet Ikot village, Ibeno, Akwa Ibom State. Dispersant was used as the only remedial measure to contain the spill. Microbial diversity of the spill site is monitored using the culture-dependent methods $[14,15]$ which is known to reveal only $<1 \%$ of the microbial population [16]. These results are unrealistic and therefore do not present the true ecological status of the site. Fourteen years after the spill, the ecological integrity of the site is questionable and appropriate remediation action can not be carried out.

Studies report that culture-dependent techniques only account for a small subset, approximately $<1 \%$ of the total microbial diversity present in the environment [17]. According to [18], it is possible to detect a wider variety of microbial diversity using metagenomic tools $[19,20]$ than by using culture-dependent methods. According to the

*Corresponding author: Udotong IR, Department of Microbiology, University of Uyo, Uyo, Akwa Ibom State, Nigeria, Tel: 08023008640; E-mail: ime.udotong@usicltd.com

Received July 22, 2015; Accepted August 24, 2015; Published August 29, 2015

Citation: Udotong IR, Uko MP, Udotong JIR (2015) Microbial Diversity of a Remote Aviation Fuel Contaminated Sediment of a Lentic Ecosystem in Ibeno, Nigeria. J Environ Anal Toxicol 5: 320. doi:10.4172/2161-0525.1000320

Copyright: (c) 2015 Udotong IR, et al. This is an open-access article distributed under the terms of the Creative Commons Attribution License, which permits unrestricted use, distribution, and reproduction in any medium, provided the original author and source are credited. 
'great plate count anomaly', it is observed that most microbes cannot be grown under laboratory conditions; some may actually be nonviable, while others may be viable but non-culturable (VBNC) [21]. This study on the microbial diversity of a remote aviation fuel-contaminated sediment of a lentic ecosystem in Ibeno, Nigeria is aimed at identifying the microbial communities that inhabit the sediment of a lentic ecosystem polluted by aviation fuel about 14 years ago using both the culture-dependent and cultureindependent (metagenomic) approaches. This is the first time, to the best of our knowledge, that metagenomic tools is used to determine the ecological integrity of any environmental media in the Niger Delta region.

\section{Materials and Methods}

\section{Site description}

The lentic ecosystem in Inua Eyet Ikot, Ibeno is located on longitude $04^{\circ} 32.647^{\prime} \mathrm{N}$, and latitude $007^{\circ} 59.95^{\prime} \mathrm{E}$. The site is located off QIT-Jetty Road in Ibeno, Akwa Ibom State, Nigeria.

\section{Sediment sample collection}

Sediment samples from this remote aviation fuel-contaminated lentic ecosystem were collected at different points using a hand-held auger into sterile polythene bags and taken to the laboratory. The samples were composited and a composite sediment sample used for the analyses.

\section{Culture methods}

Serial dilution: Ten-fold serial dilutions of the sediment samples were made as described by the American Public Health Association $[22,23]$.

Inoculation and incubation: One milliliter of appropriate ten-fold serial dilutions of the sediment samples were inoculated onto nutrient agar (Oxoid CM 314), malt extract agar (Oxoid) and sabouraud dextrose agar plates in triplicates using pour plate methods [22,23] and spread plates methods $[24,25]$. The hydrocarbon utilizing bacterial counts (HUB) were enumerated by the spread plate technique using oilmineral salt medium (MSM) [26]. The media were supplemented with cycloheximide $(100 \mu \mathrm{g} / \mathrm{ml}$ and benomyl $(50 \mu \mathrm{g} / \mathrm{ml})$ to prevent fungal growth (Eka and Forgathy, 1972). The crude oil used was sterilized by filtering through Millipore filter $(0.45 \mu \mathrm{m}$ pore size $)$ and stored in sterile bottles. Inoculated plates were incubated at $28 \pm 2^{\circ} \mathrm{C}$ for $18-24$ $\mathrm{hr}$ and $48-72 \mathrm{hr}$ for the enumeration of total heterotrophic bacteria and fungi, respectively. Visible discrete colonies in incubated plates were counted and plates with population densities that ranged from 30 and 300 colonies were multiplied by the reciprocal of the dilution factor and expressed as colony forming units per gram (cfu/g) of sediment samples.

Maintenance of pure culture: Discrete colonies were purified by repeated sub-cultures unto appropriate agar media. Pure cultures were preserved on nutrient agar slants and stored in the refrigerator $\left(4^{\circ} \mathrm{C} \pm\right.$ $\left.2^{\circ} \mathrm{C}\right)$ and at ambient temperature $\left(28^{\circ} \mathrm{C} \pm 2^{\circ} \mathrm{C}\right)$ for further tests.

Characterization and identification of microbial isolates: Pure cultures of microbial isolates were identified based on cultural parameters, microscopic techniques and biochemical tests including carbohydrate utilization [27]. Identification of the bacterial isolates was accomplished by comparing the characteristics of the cultures with that of known taxa as in ref. [28]. Characterization and identification of fungal isolates was carried out as in ref. [29,30].

\section{S Metagenomic (culture-independent) methods}

DNA extraction and purification: Community/metagenomic DNA was extracted from the sediment sample using the Zymo soil DNA extraction Kit (Model D 6001, Zymo Research, USA) following the manufacturer's instructions [31]. The purity as well as the quantity of the extracted DNA was examined by recording its UV absorption spectrum using NanoDrop spectrophotometer and running the DNA in $1 \%$ agarose gel electrophoresis.

DNA amplification and sequencing: The extracted DNA was amplified by Polymerase chain reaction (PCR) using primers pairs 27F: 5'-GAGTTTGATCCTGGCTCAG-3' and 518R: 5'ATTACCGCGGCTGCTGG - 3' as forward and reverse primers, respectively. Successful amplification of DNA was verified by electrophoresis. The nucleotide sequence of the purified products was determined by Next Generation Sequencing (NGS) technique in an automated PCR cycle-Genome Sequencer ${ }^{\mathrm{m}}$ MiSeq (Illuminar). Analysis and alignment was performed using Vector NTI Suite 9 (InforMax, Inc; USA). Overall bioinformatics analysis was done using NCBI-BLAST-2.2.24 and CLC BioGenomics workbench v7.5.1.

\section{Results and Discussion}

\section{Results of culture-dependent techniques}

Microbial counts: Microbial growths were found on nutrient agar medium at dilutions $10^{-1}$ to $10^{-3}$, blood agar medium at dilutions $10^{-1}$ and $10^{-2}$, Mineral salt medium at dilution $10^{-1}$ and $10^{-2}$, mannitol salt agar medium at dilutions $10^{-1}$ and $10^{-4}$, and on MaConkey agar medium at dilution $10^{-1}$. The rest of the media had no visible growth (Table 1a).

Microbial counts of the aviation fuel-polluted sediment of the lentic ecosystem using the culture-dependent techniques are as presented on (Table 1b) as the microbial counts.

The characteristics of the prokaryotic organisms isolated from the sediment samples from the remote aviation fuel-contaminated site using conventional microbiological culture-dependent methods are presented on Table 2 . They were classified into the different taxonomic groups as shown on Table 3 .

\section{Microbial diversity using Metagenomic (culture-independent) tools}

Summary of sequencing statistics and classification rate: The sequencing statistics showing total reads and reads passing quality filtering used for the 16S Metagenomic analyses are as shown on Table 4 and the summary of the classification rate are shown on Table 5.

Figure 1 shows the summary of the classification rate of the prokaryotic organisms present in the aviation fuel-contaminated lentic sediment by taxonomic levels.

The 16S Metagenomic analyses of the sediment from a remote aviation fuel-contaminated lentic ecosystem shows that the prokaryotic composition were classified into bacteria with 17,100 reads $(91.0 \%)$, archaea with 697 reads $(3.71 \%)$ and 995 reads $(5.29 \%)$ were unclassified at the kingdom level, suspected to belong to the third kingdom (domain), the eukaryota (Figure 2).

This $16 \mathrm{~S}$ metagenomic tool was able to identify the organisms into the different domains; the bacteria, archaea and the other unclassified, suspected to be the third domain, the eukaryota. The results of this $16 \mathrm{~S}$ metagenomic report also identified and thus classified all the procaryotic organisms present at this remote aviation fuel-contaminated lentic 


\begin{tabular}{|l|c|c|c|c|c|}
\hline \multirow{2}{*}{\multicolumn{1}{c|}{ Culture Medium }} & \multicolumn{5}{|c|}{ Dilution Factor } \\
\cline { 2 - 7 } & $\mathbf{1 0}^{-\mathbf{1}}$ & $\mathbf{1 0}^{-\mathbf{2}}$ & $\mathbf{1 0}^{-\mathbf{3}}$ & $\mathbf{1 0}^{-\mathbf{4}}$ & $\mathbf{1 0}^{-\mathbf{5}}$ \\
\hline Nutrient Agar & 90 & 31 & 10 & $\mathrm{NG}$ & - \\
\hline Blood Agar & 23 & 9 & NG & - & - \\
\hline Thiosulphate Citrate Bile Salt (TCBS) & NG & - & - & - & - \\
\hline Starch Nitrate Agar (SNA) & 2 & NG & - & - & - \\
\hline Mineral Salt Medium (MSM) & 31 & 19 & NG & - & - \\
\hline Manitol Salt Agar (MSA) & 1 & NG & - & - & - \\
\hline MacConkay Agar (MCA) & 6 & NG & - & - & - \\
\hline Basal Salt Medium (BSM) & NG & - & - & - & - \\
\hline Salmonella-Shigella Medium (SSA) & NG & - & - & - & - \\
\hline Sulphate Solubilizing Bacterial Agar (SSBA) & NG & - & - & - & - \\
\hline Phosphate Solubilizing Bacterial Agar (PSBA) & NG & - & - & - & - \\
\hline Eosin Methylene Blue Agar (EMBA) & NG & - & - & - & - \\
\hline
\end{tabular}

Table 1a: Counts of microbial cells using culture-dependent techniques. NG: No growth.

\begin{tabular}{|c|c|}
\hline Culture medium & Microbial counts (cfu/g) \\
\hline Nutrient Agar (NA) & $3.1 \times 10^{3}$ \\
\hline Mineral Salt Medium (MSM) & $3.1 \times 10^{2}$ \\
\hline
\end{tabular}

Table 1b: Viable counts of microbial cells using culture-dependent techniques.

sediment into their various taxonomic groups including phylum, class, order, family, genus and species.

Prokaryotic organisms belonging to 27 Phyla were detected using this 16S metagenomic tool. Table 6 shows that the top 7 of 27 phyla (with the number of reads) belonged to the Phyla Firmicutes (9.65\%), Proteobacteria (49.74\%), Actinobacteria (5.58\%), Chloroflexi (4.99\%), Acidobacteria (3.94\%), Bacteroidetes (2.89\%), and Euryarchaeota (2.87\%). At this level, $11.24 \%$ were unclassified. Figure 3 shows the top 5 of 27 phyla $(70.05 \%)$ while the unclassified and others make up the remaining $15.90 \%$ and $14.05 \%$, respectively.

A total of 57 classes of prokaryotic organisms were detected from the remote aviation fuel-contaminated lentic sediment. The top 7 of 57 classes (Table 7) were identified to be Betaproteobacteria (17.01\%), Deltaproteobacteria (11.61\%), Gammaproteobacteria (10.21\%), Alphaproteobacteria (9.63\%), Clostridia (6.81\%), Actinobacteria (5.09\%) and Anaerolineae (4.44\%) (Figure 4).

A total of 109 orders of prokaryotic organisms were identified from the remote aviation fuel-contaminated lentic sediment in Ibeno, Nigeria. Table 8 presents the reads and percent of total reads of the top 7 of 109 orders while Figure 5 gives the orders as Actinomycetales (4.59\%), Clostridiales (4.66\%), Pseudomonadales (4.89\%), Rhizobiales (5.63\%), Rhodocyclales (16.26\%), Anaerolineales (4.31\%) and Burkholderiales (3.85\%).

The 16S metagenomic result of the remote aviation fuelcontaminated lentic sediment identified and thus classified all the procaryotic organisms present into a total of 224 families. Table 9 presents the identities of the top 7 of the 224 families as Rhodocyclaceae (10.92\%), Pseudomonadaceae (4.58\%), Anaerolinaceae (4.31\%), Comamonadaceae (2.93\%), Clostridiaceae (2.79\%), Acidobacteriaceae (2.29\%), and Hyphomicrobiaceae (2.12\%). A total of $19.86 \%$ were unclassified.

A total of 498 genera of prokaryotic organisms were identified from the remote aviation fuel-contaminated lentic sediment at Ibeno, Nigeria. The identities of the top 7 of the 498 genera were presented in Table 10 as Zoogloea (5.58\%), Pseudomonas (3.83\%), Longilinea (1.96\%), Edaphobacter (1.86\%), Clostridium (1.64\%), Geobacter
(1.60\%), and Candidatus blochmannia (1.60\%). The eighth most predominant group was unclassified (26.06\%).

Using the $16 \mathrm{~S}$ metagenomic tools, a total of 718 prokaryotic species were identified to be present in the remote aviation fuel-contaminated lentic sediment at Ibeno, Nigeria. The seven most predominant species (Table 11) were identified to be Zoogloea resiniphila (5.52\%), Longilinea arvoryzae (1.93\%), Edaphobacter modestus (1.86\%), Candidatus blochmannia rufipes (1.58\%), Peptoniphilus coxii (1.02\%), Uliginosibacterium gangwonense (1.00\%) and Chondromyces pediculatus $(0.94 \%)$. Of this 718 species, $50.43 \%$ of the species were considered unclassified.

In summary, the prokaryotic composition of the aviation fuelcontaminated lentic site was so diverse that 718 different species, 498 genera, 224 families, 109 orders, 57 classes, 27 phyla and 2 domains (excluding those unclassified) (Table 12) were identified using the $16 \mathrm{~S}$ metagenomic tools as compared to the results obtained using the culture-dependent techniques. It is important to note that the pie chart shows only all classifications above $3.5 \%$ abundance while the "other" category in the pie chart is the sum of all classifications with less than $3.5 \%$ abundance.

Comparatively, the culture-dependent method of microbial identification showed limited microbial diversity right from the kingdom level to the species level than the culture-independent techniques (Table 12).

Ribosomal sequences are present in all organisms, and serve as phylogenetic markers which allow organisms to be distinguished on all phylogenetic levels. Metagenomics investigation to ascertain the true composition of the microbial community present in the sediment sample revealed complex consortia of prokaryotes which have been extensively documented in hydrocarbon-contaminated environments as well as during oil degradation [32]. Based on the quality of the metagenomic data set and the read length of the DNA fragments, the results showed that bacteria are the predominant group with $91.7 \%$ in the polluted sediment. This high degree of occurrence recorded by bacteria agrees with a study by ref. [33], which reports that by the evolution of enhanced hydrocarbon degradation which horizontal gene transfer is a major force, bacterial community structure changes and proliferation takes place in response to hydrocarbon pollution. Also, bacteria is said to utilize hydrocarbons as carbon and energy source more than any other microbial group. They have been shown to be more versatile than even fungi and therefore may play a greater role during biodegradation of hydrocarbons [34].

The 16S rRNA sequences detected in the investigated sediment samples, showed the highest similarities to those of the organisms Zoogloea resiniphila (5.52\%), Longilinea arvoryzae (1.93\%), Edaphobacter modestus (1.86\%), Candidatus blochmannia rufipes (1.58\%), Peptoniphilus coxii (1.02\%), Uliginosibacterium gangwonense (1.00\%), Chondromyces pediculatus (0.94\%). Other members of the complex bacterial community identified from the remote aviation fuelcontaminated site included Ralstonia sp., Nostocoida limicola III strain Ben222, N. moscoviensis, Ehrlichia sp. HI-2000, Waddlia sp. G817, Geobacter bremensis strain Dfr1, Arthrobacter uratoxydans strain DSM 20647, Enterococcus faecium, Mycobacterium scrofulaceum, Leptospira parva, Azovibrio sp., Bacillus sphaericus, Massilia timonae, Roseateles depolymerans strain 61B2, Rhodovulum sp., Modestobacter versicolor strain CP153-2, Streptomyces sp., Neochlamydia hartmannellae strain A1Hsp, Desulfovibrio idahonensis, D. fructosivorans strain JJ, Anabaenopsis circularis NIES21, Lactobacillus rhamnosus strain PL60, Candidate division OP11 clone LGd8, Alcanivorax sp., Saccharococcus 


\begin{tabular}{|c|c|c|c|c|c|c|c|c|c|c|c|c|c|c|c|c|c|c|c|}
\hline 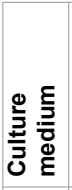 & $\begin{array}{l}\text { 흐 } \\
\frac{0}{0} \\
\frac{\vdots}{2} \\
\frac{0}{0} \\
\Sigma\end{array}$ & 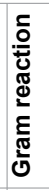 & $\frac{\searrow}{\bar{\Xi}}$ & 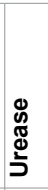 & 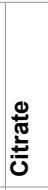 & 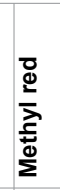 & 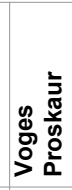 & $\frac{\gtrless}{\stackrel{Z}{Z}}$ & 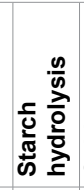 & 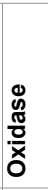 & \begin{tabular}{l}
0 \\
$\mathscr{D}$ \\
$\frac{\pi}{\pi}$ \\
\multirow{N}{\pi}{} \\
0
\end{tabular} & 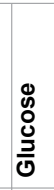 & 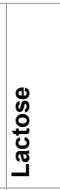 & 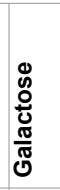 & 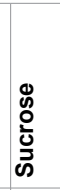 & 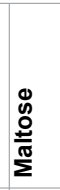 & 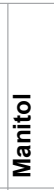 & 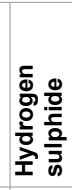 & 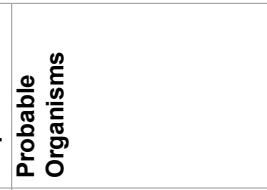 \\
\hline NA & $\begin{array}{l}\text { Irregular, flat, brown, and } \\
\text { undulated colony }\end{array}$ & - & Rod & + & + & - & + & + & - & - & + & $\mathrm{Ag}$ & A & A & A & $\mathrm{Ag}$ & & - & Xanthomonas sp. \\
\hline NA & $\begin{array}{l}\text { Regular, cream, and raised } \\
\text { colony }\end{array}$ & + & Rod & - & + & + & - & + & - & - & + & $\mathrm{Ag}$ & - & A & $\mathrm{Ag}$ & A & - & - & Bacillus subtilis \\
\hline NA & $\begin{array}{l}\text { Regular, cream, and raised } \\
\text { colony }\end{array}$ & + & Cocci & - & + & + & - & - & + & + & + & $\mathrm{Ag}$ & - & A & A & A & & + & Micrococcus sp. \\
\hline NA & $\begin{array}{l}\text { Regular, cream and entire } \\
\text { colony }\end{array}$ & + & Cocci & + & + & - & + & - & - & - & + & A & - & A & A & $\mathrm{Ag}$ & - & & Staphylococcus albus \\
\hline NA & $\begin{array}{l}\text { Milky, viscous, and opaque } \\
\text { colony. Odour present }\end{array}$ & - & Rod & + & + & - & + & + & - & - & + & $\mathrm{Ag}$ & $\mathrm{Ag}$ & $\mathrm{Ag}$ & $\mathrm{Ag}$ & $\mathrm{Ag}$ & & + & Proteus sp. \\
\hline BA & $\begin{array}{l}\text { Irregular, flat, cream, and erose } \\
\text { colony }\end{array}$ & + & Rod & - & + & - & + & + & - & + & - & $\mathrm{Ag}$ & - & A & $\mathrm{Ag}$ & A & - & + & Lactobacillus sp. \\
\hline BA & $\begin{array}{l}\text { Filamentous, flat, cream, lobate } \\
\text { colony }\end{array}$ & + & Rod & + & + & - & + & + & - & + & + & $\mathrm{Ag}$ & - & A & A & A & - & - & B. cereus \\
\hline
\end{tabular}

Table 2: Characteristics of microbial isolates from sediment samples using culture-dependent techniques. NA: Nutrient Agar; BA: Blood Agar; A: Acid; Ag: Acid and gas.

\begin{tabular}{|c|c|}
\hline Taxonomic Level & Frequency \\
\hline Phylum & 1 \\
\hline Class & 3 \\
\hline Order & 4 \\
\hline Family & 5 \\
\hline Genus & 5 \\
\hline Species & 6 \\
\hline
\end{tabular}

Table 3: Classification of isolates from Culture-Dependent methods into taxonomic groups.

\begin{tabular}{|l|l|l|}
\hline Total Reads & $\begin{array}{l}\text { Reads Passing Quality } \\
\text { Filtering }\end{array}$ & $\begin{array}{l}\text { \% Reads Passing Quality } \\
\text { Filtering }\end{array}$ \\
\hline 20,157 & 18,792 & $93.2 \%$ \\
\hline
\end{tabular}

Table 4: Sequencing statistics.

\begin{tabular}{|l|l|l|}
\hline Taxonomic Level & $\begin{array}{l}\text { Reads Classified to } \\
\text { Taxonomic Level }\end{array}$ & $\begin{array}{l}\text { \% Total Reads Classified to } \\
\text { Taxonomic Level }\end{array}$ \\
\hline Kingdom & 17,797 & $94.71 \%$ \\
\hline Phylum & 16,680 & $88.76 \%$ \\
\hline Class & 16,371 & $87.12 \%$ \\
\hline Order & 15,736 & $83.74 \%$ \\
\hline Family & 15,059 & $80.14 \%$ \\
\hline Genus & 13,894 & $73.94 \%$ \\
\hline Species & 9,316 & $49.57 \%$ \\
\hline
\end{tabular}

Table 5: Classification rate summary.

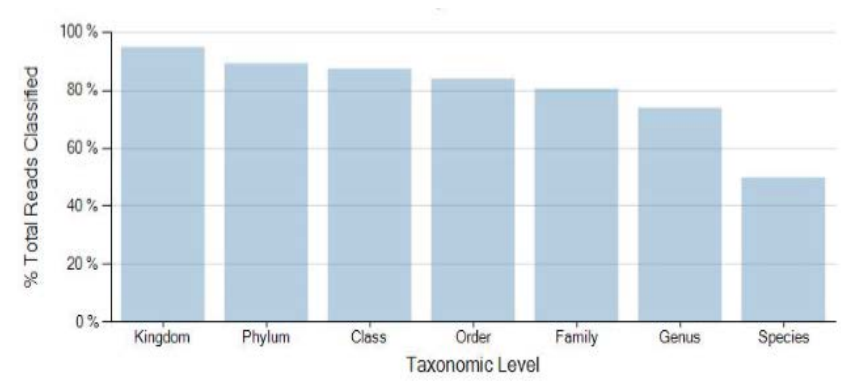

Figure 1: Summary of the classification rate by taxonomic levels.

thermophiles strain 657, Pseudoalteromonas sp., Pseudomonas sp., Shewanella benthica, Sphingomonas panni strain C52, Pseudomonas pseudoalcaligenes strain M5-4, etc.
Uncultured bacteria were also detected by the $16 \mathrm{~S}$ metagenomic methods to include the uncultured Clostridiaceae bacterium, uncultured Holophaga sp (AJ519667.1), uncultured Antarctic cyanobacterium clone FreP09 (AY541579.1), uncultured Pedomicrobium sp. clone Oversite 90 (AY647328.1), uncultured Nitrospirae bacterium clone AKYG1809 (AY921744.1), uncultured Bacteroidetes bacterium clone LiUU-9-73 (AY509370.1), and a host of others. This strongly implies that these group cannot be cultured which confirms the "great plate anomaly".

The 16S rRNA metagenomic analysis detected archaeal 16S rRNA sequences of Methanococcus maripaludis (AF005049.1), the uncultured Methanosarcinaceae archaeon (AJ879043.1), uncultured archaeon (AJ310855.1), anaerobic methanogenic archaeon (AJ244295.1), an unidentified archaeon (Y15393.1), Methanococcus aeolicus (DQ136171.1), uncultured Methanosaeta sp. etc.

Majority of the microbial cells revealed by the culture-independent methods were not encountered in the culture-dependent approach. This justifies the inefficiency of the conventional culture-dependent techniques. The use of $16 \mathrm{~S}$ Metagenomics approaches will bypasses the need for microbial cultivation as majority of microbial species in any environment prove uncultivable in the laboratory mainly due to the lack of knowledge of the real conditions under which these bacteria grow in their natural environment [34]. Microbial identification by metagenomics approach therefore results in the discovery of unique and unrecognized microorganisms as well as complex microbial diversity in contaminated samples, thus revealing the true ecological status of any investigated environment. The very few (only 6) species of bacteria and no Archaean member revealed by the conventional culture-dependent methods obtained in this study is not surprising as the method identifies only the few microorganisms that can only be cultivated in the laboratory.

Crude oil and other petroleum hydrocarbons are not only found at the site of oil pollution, but are chemically heterogeneous and almost ubiquitous in the environment including most pristine soils and sediments [35] following seepage from natural deposits and biosynthesis by plants and microorganisms [36,37]. However, the effect of an oil spill is believed to cause the presence of a more diverse oil-degrading microbial community, ultimately leading to a microbial community that will be more efficient at degrading crude oil, should another accidental spill take place. The results from this study revealed efficient hydrocarbon-utilizers from this remote aviation 
Citation: Udotong IR, Uko MP, Udotong JIR (2015) Microbial Diversity of a Remote Aviation Fuel Contaminated Sediment of a Lentic Ecosystem in Ibeno, Nigeria. J Environ Anal Toxicol 5: 320. doi:10.4172/2161-0525.1000320

Page 5 of 7

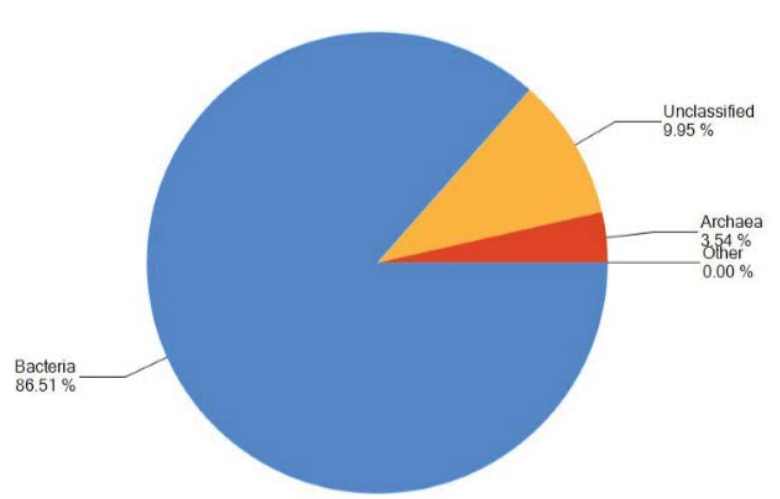

Figure 2: Kingdom (domain) classification of microorganisms in sediment from a remote aviation fuel-contaminated lentic ecosystem.

\begin{tabular}{|l|l|l|}
\hline Classification & Number of Reads & $\%$ Total Reads \\
\hline Proteobacteria & 9,347 & $49.74 \%$ \\
\hline Unclassified at Phylum level & 2,112 & $11.24 \%$ \\
\hline Firmicutes & 1,813 & $9.65 \%$ \\
\hline Actinobacteria & 1,048 & $5.58 \%$ \\
\hline Chloroflexi & 937 & $4.99 \%$ \\
\hline Acidobacteria & 741 & $3.94 \%$ \\
\hline Bacteroidetes & 543 & $2.89 \%$ \\
\hline Euryarchaeota & 539 & $2.87 \%$ \\
\hline
\end{tabular}

Table 6: Top 7 of 27 Phyla classification.

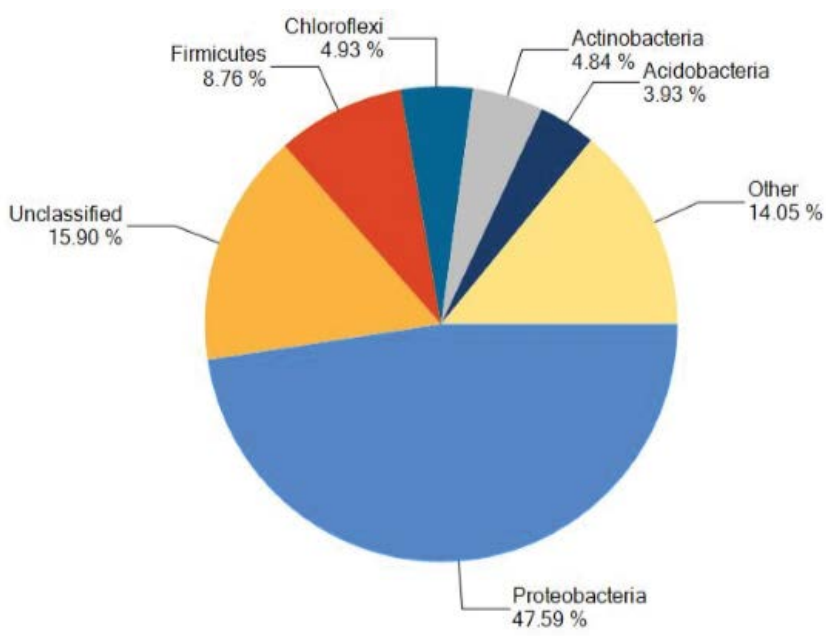

Figure 3: Top 5 of 27 Phyla Classification.

\begin{tabular}{|l|l|l|}
\hline Classification & Number of Reads & \% Total Reads \\
\hline Betaproteobacteria & 3,197 & $17.01 \%$ \\
\hline Unclassified at Class level & 2,421 & $12.88 \%$ \\
\hline Deltaproteobacteria & 2,181 & $11.61 \%$ \\
\hline Gammaproteobacteria & 1,919 & $10.21 \%$ \\
\hline Alphaproteobacteria & 1,810 & $9.63 \%$ \\
\hline Clostridia & 1,280 & $6.81 \%$ \\
\hline Actinobacteria & 956 & $5.09 \%$ \\
\hline Anaerolineae & 835 & $4.44 \%$ \\
\hline
\end{tabular}

Table 7: Top 7 of 57 Classes classification.

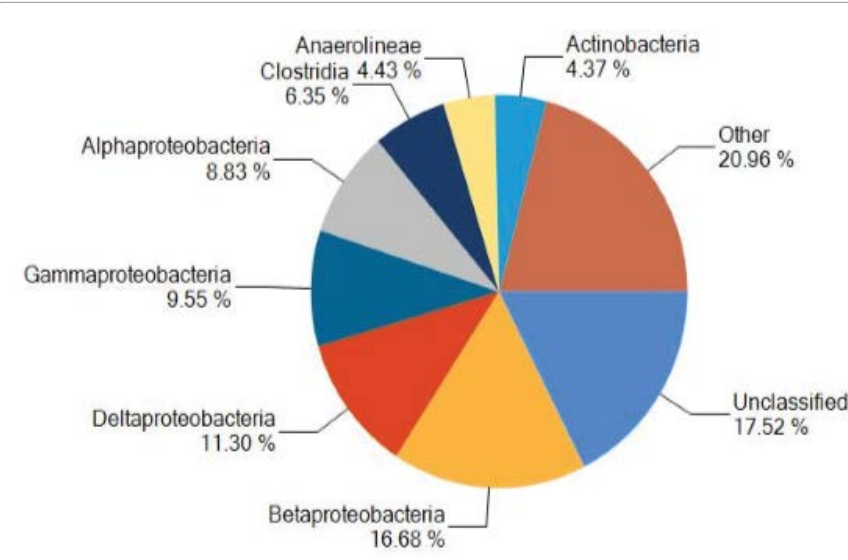

Figure 4: Top 7 of 57 Classes Classifications.

\begin{tabular}{|l|l|l|}
\hline Classification & Number of Reads & $\%$ Total Reads \\
\hline Unclassified at Order level & 3,056 & $16.26 \%$ \\
\hline Rhodocyclales & 2,053 & $10.92 \%$ \\
\hline Rhizobiales & 1,058 & $5.63 \%$ \\
\hline Pseudomonadales & 919 & $4.89 \%$ \\
\hline Clostridiales & 876 & $4.66 \%$ \\
\hline Actinomycetales & 862 & $4.59 \%$ \\
\hline Anaerolineales & 810 & $4.31 \%$ \\
\hline Burkholderiales & 724 & $3.85 \%$ \\
\hline
\end{tabular}

Table 8: Top 7 of 109 Orders classification.

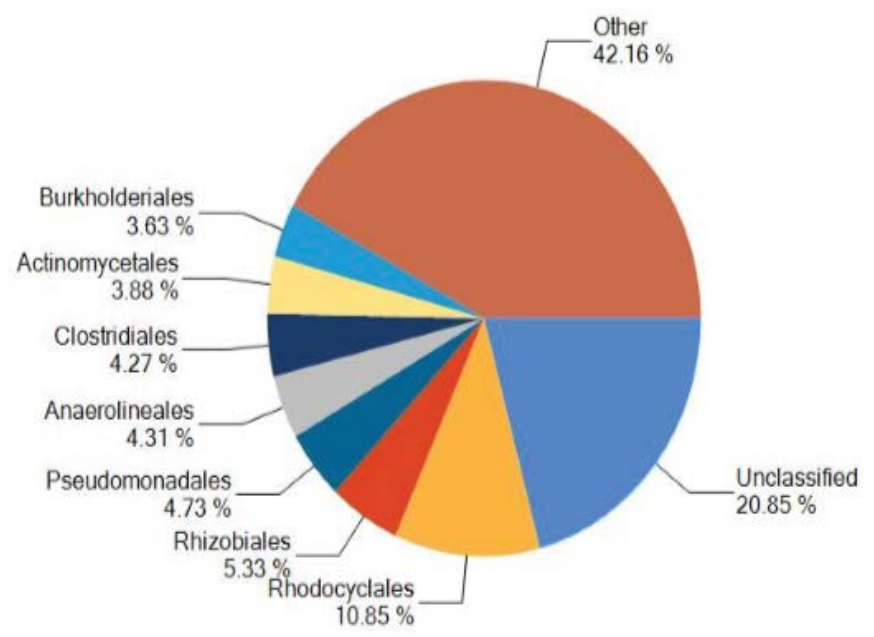

Figure 5: Top 7 of 109 Orders Classifications.

\begin{tabular}{|l|l|l|}
\hline Classification & Number of Reads & $\%$ Total Reads \\
\hline Unclassified at Family level & 3,733 & $19.86 \%$ \\
\hline Rhodocyclaceae & 2,053 & $10.92 \%$ \\
\hline Pseudomonadaceae & 861 & $4.58 \%$ \\
\hline Anaerolinaceae & 810 & $4.31 \%$ \\
\hline Comamonadaceae & 551 & $2.93 \%$ \\
\hline Clostridiaceae & 525 & $2.79 \%$ \\
\hline Acidobacteriaceae & 431 & $2.29 \%$ \\
\hline Hyphomicrobiaceae & 399 & $2.12 \%$ \\
\hline
\end{tabular}

Table 9: Top 7 of 224 Families classification. 
Citation: Udotong IR, Uko MP, Udotong JIR (2015) Microbial Diversity of a Remote Aviation Fuel Contaminated Sediment of a Lentic Ecosystem in Ibeno, Nigeria. J Environ Anal Toxicol 5: 320. doi:10.4172/2161-0525.1000320

Page 6 of 7

\begin{tabular}{|l|l|l|}
\hline Classification & Number of Reads & $\%$ Total Reads \\
\hline Unclassified at Genus level & 4,898 & $26.06 \%$ \\
\hline Zoogloea & 1,049 & $5.58 \%$ \\
\hline Pseudomonas & 719 & $3.83 \%$ \\
\hline Longilinea & 368 & $1.96 \%$ \\
\hline Edaphobacter & 350 & $1.86 \%$ \\
\hline Clostridium & 308 & $1.64 \%$ \\
\hline Geobacter & 300 & $1.60 \%$ \\
\hline Candidatus blochmannia & 300 & $1.60 \%$ \\
\hline
\end{tabular}

Table 10: Top 7 of 498 Genera classification.

\begin{tabular}{|l|l|l|}
\hline Classification & Number of Reads & $\%$ Total Reads \\
\hline Unclassified at Species level & 9,476 & $50.43 \%$ \\
\hline Zoogloea resiniphila & 1,037 & $5.52 \%$ \\
\hline Longilinea arvoryzae & 363 & $1.93 \%$ \\
\hline Edaphobacter modestus & 350 & $1.86 \%$ \\
\hline Candidatus blochmannia rufipes & 296 & $1.58 \%$ \\
\hline Peptoniphilus coxii & 192 & $1.02 \%$ \\
\hline Uliginosibacterium gangwonense & 188 & $1.00 \%$ \\
\hline Chondromyces pediculatus & 177 & $0.94 \%$ \\
\hline
\end{tabular}

Table 11: Top 7 of 718 Species classification.

\begin{tabular}{|l|l|l|}
\hline \multirow{2}{*}{ Taxonomic level } & Total Number of Classifications \\
\cline { 2 - 3 } & $\mathbf{1 6 S}$ Metagenomics tools & Culture-dependent methods \\
\hline Kingdom & $\mathbf{2}$ & $\mathbf{1}$ \\
\hline Phylum & 27 & 2 \\
\hline Class & 57 & 3 \\
\hline Order & 109 & 4 \\
\hline Family & 224 & 5 \\
\hline Genus & 498 & 5 \\
\hline Species & 718 & 6 \\
\hline
\end{tabular}

Table 12: Summary of classification at taxonomic level.

fuel-polluted site; namely, species of Bacillus, xanthomonas, Micrococcus, Staphylococcus, Arthrobacter, Nocardia, Pseudomonas, Azospirillum, Dechloromonas, Streptomyces, Sphingomonas, Ralstonia, Proteus, among others as reported by ref. $[34,38,39]$. These group of microorganisms are commonly associated with oil-contaminated ecosystems due to their high osmophilic properties [40,41], implying that the microbial communities of an ecosystem can provide information on the health of that ecosystem.

\section{Conclusions}

In conclusion, as low as six species of bacteria with no archaeal representative were detected from the conventional culture-dependent techniques while the $16 \mathrm{~S}$ metagenomic analysis detected a total of 718 microbial species comprising both bacterial and archaeal diversity. Comparing the efficiency of both approaches adopted, this study confirms and thus supports the "great plate count anomaly" as well as support the adoption of the $16 \mathrm{~S}$ metagenomic and other complimentary OMICS tools to investigate the true ecological integrity of any investigated environment.

\section{Acknowledgements}

Prof. I. R. Udotong is grateful to Dr. Mrs. Francisca Oby Nwaokorie of the Molecular Biology and Biotechnology Division of the Nigerian Institute of Medical Research, Yaba, Lagos, Nigeria for her technical assistance in Community DNA extraction, sequencing and bioinformatics analyses.

\section{References}

1. Onyemaechi JO (2012) Economic Implications of Petroleum Policies in Nigeria: An Overview. American International Journal of Contemporary Research 2: 60-71.

2. Scheren PA, Ibe AC, Janssen FJ, Lemmens AM (2002) Environmental pollution in the Gulf of Guinea-a regional approach. Mar Pollut Bull 44: 633-641.

3. Guerra K, Dahm K, Dundorf S (2011) Oil and gas produced water management and beneficial use in the Western United States, U.S. Department of the Interio Bureau of Reclamation, Science and Technology Program Report No. 157 Technical Service Center.

4. Egwu SA (2012) Oil Spill Control and Management. An International Journal of Petroleum Technology Development 1: 1-6.

5. Udotong IR, Udotong JIR, John OUM (2015) Delineation of Oil - Polluted Sites in Ibeno LGA, Nigeria Using Microbiological and Physicochemical Characterization. Proceedings of the International Conference of the World Academy of Science, Engineering and Technology (WASET) in New York, USA

6. Eka OU, Udotong IR (2003) A case study of effects of Incessant Oil Spills from Mobil producing Nigeria Unlimited on Human Health in Akwa Ibom State. In Environmental Pollution and Management in the Tropics (Adinna EN, Ekop OB Attah VI (Eds)) SNAAP Press Ltd, Enugu, Nigeria, 205-229.

7. Oviasuyi PO, Uwadiae J (2010) The Dilemma of Niger-Delta Region as Oil Producing States of Nigeria. Journal of Peace, Conflict and Development 16: 1-110.

8. Daily Trust (2009) Nigeria: Akwa Ibom Overtakes Rivers As Richest Oil State.

9. Asoya SI (2012) The Impact of Oil Spillage on Agricultural Production: A case study of Ibeno Local Government Area, Akwa-Ibom State, Nigeria. University of the Free State, Bloemfontein, South Africa.

10. Nwilo CP, Badejo TO (2005) Impacts and Management of Oil Spill Pollution along the Nigerian Coastal Areas. Department of Survey \& Geoinformatics, University of Lagos, Lagos, Nigeria.

11. Vanguard Newspaper (2011) November 252011.

12. Obeche P (2010) Oil spills in Nigeria. Pers Comm Warri 19/12/2010.

13. Eka OU, Fogathy NM (1972) Descriptive studies on a Streptomyces species part 1. Description and some properties of the microorganisms. West African Journal of Biological and Applied Chemistry 3: 11-17.

14. Udotong IR (2010) Oil-impacted sites in Ibeno LGA: A Technical Report submitted by Page Environmental Ltd to Ministry of Niger Delta Affairs, Abuja.

15. Udotong IR, Udotong JIR, Antia EE, Onochie MC, Akpan AW (2011) Microbial and Hydrobiological Indicators and Physicochemical Characteristics of a Remote Aviation Fuel-Contaminated Lentic System in Ibeno, Nigeria. Proceedings of the 5th European Bioremediation Conference holding at Chania, Crete, Greece.

16. Cowan D, Meyer Q, Stafford W, Muyanga S, Cameron R, et al. (2005) Metagenomic gene discovery: past, present and future. Trends Biotechnol 23: 321-329.

17. Tyson GW, Banfield JF (2005) Cultivating the uncultivated: a community genomics perspective. Trends Microbiol 13: 411-415

18. Laiz L, Recio D, Hermosin B, Saiz-Jimenez C (2000) Microbial communities in salt efflorescences, In: Ciferri O, Tiano P, Mastromei G, (eds) On Microbes and Art. Proceedings of an International Conference on Microbiology and Conservation (ICMC). Kluwer Academic/Plenum Publishers, New York. pp. 77-88.

19. Gentile G, Giuliano L, D'Auria G, Smedile F, Azzaro M, et al. (2006) Study of bacterial communities in Antarctic coastal waters by a combination of $16 \mathrm{~S}$ rRNA and 16S rDNA sequencing. Environ Microbiol 8: 2150-2161.

20. Thiyagarajan V, Lau S, Tsoi M, Zhang W, Qian PY (2010) Monitoring Bacterial Biodiversity in Surface Sediment Using Terminal Restriction Fragment Length Polymorphism Analysis (T-RFLP): Application to Coastal Environment Ishimatsu A, Lie HJ (Eds) Coastal Environmental and Ecosystem Issues of the East China Sea. 151-163.

21. Staley JT, Konopka A (1985) Measurement of in situ activities of nonphotosynthetic microorganisms in aquatic and terrestrial habitats. Annu Rev Microbiol 39: $321-346$

22. American Public Health Association; APHA (1989) Standard Methods for the examinations of water and wastewaters (17th edn) Publishers: American Public Health Association; American Water Works Association and Water Pollution Control Federation.

23. Collins CH, Lyne PM (1976) Microbiological Methods. 4th edn. Butterworth and Co London. pp. 401-433.

24. Harrigan EF, McCance ME (1976) Laboratory Methods in Food and Dairy Micobiology. London: Academic press 18: 226-227. 
Citation: Udotong IR, Uko MP, Udotong JIR (2015) Microbial Diversity of a Remote Aviation Fuel Contaminated Sediment of a Lentic Ecosystem in Ibeno, Nigeria. J Environ Anal Toxicol 5: 320. doi:10.4172/2161-0525.1000320

25. Demain AL, Davies JE (1999) Manual of industrial Microbiology and Biotechnology. 2nd edn Washington DC: American Society for Microbiology Press 1-830.

26. Miller DN, Bryant JE, Madsen EL, Ghiorse WC (1999) Evaluation and optimization of DNA extraction and purification procedures for soil and sediment samples. Appl Environ Microbiol 65: 4715-4724.

27. Cruickshank R, Duguid JP, Mamion RP, Swain RHA (1975) Medical Microbiology. Vol. II, London: Churchill, Livngstone 1-587.

28. Holt JG, Krieg NP, Sneath PHA, Staley J, Williams ST (1994) Bergey's manua of determination bacteriology, 9th Edn. Williams and Wilkins Publishers, Baltimore 787- 921

29. Domsch KH, Gams H, Anderson TH (1980) Compendium of Soil Fungi London Academy Press. 1-672.

30. Barnet HL, Hunter BB (1987) Ilustrated Genera of Imperfect Fungi. 4th Edition USA: Macmillan Publishing Company. 1-228

31. Dijkmans R, Jagers A, Kreps S, Collard JM, Mergeay M (1993) Rapid method for purification of soil DNA for hybridization and PCR analysis. Microb Releases 2: $29-34$

32. Zrafi-Nouira I, Saidane-Mosbahi D, Abdelghani S, Bakhrouf A, Rouabhia M (2012) Crude Oil Metagenomics for Better Bioremediation of Contaminated Environments, In: Introduction to Enhanced Oil Recovery (EOR) Processes and Bioremediation of Oil-Contaminated Sites, Romero-Zerón, L. (Ed.), ISBN: 978-953-51-0629-6, InTech. http://www.intechopen.com/books/introductionto-enhanced-oil-recoveryeor-processes-and-bioremediation-of-oil-contaminated-sites/crude-oilmetagenomics-for-better-bioremediation-of-contaminated-environments
33. Obayori SO, Salam LB (2010) Degradation of polycyclic aromatic hydrocarbons: role of plasmids. Sci Res Ess 5: 4093-4106.

34. Chikere CB, Okpokwasili GC, Chikere BO (2011) Monitoring of microbial hydrocarbon remediation in the soil. 3 Biotech 1: 117-138.

35. Quatrini P, Scaglione G, De Pasquale C, Riela S, Puglia AM (2008) Isolation of Gram-positive n-alkane degraders from a hydrocarbon-contaminated Mediterranean shoreline. J Appl Microbiol 104: 251-259.

36. Atlas RM, Philp J (2005) Bioremediation: applied microbial solutions for realworld environmental cleanup. American Society for Microbiology (ASM) Press, Washington DC. pp. 78-105.

37. Ollivier B, Magot B (2005) Petroleum Microbiology. American Society for Microbiology (ASM) Press, Washington, DC.

38. Udotong IR (2000) Environmental Monitoring and effect of petroleum production effluent on some biota of the lower Qua lboe River estuary. PhD Dissertation. Rivers State University of Science \& Technology, Nkpolu, Port Harcourt, Nigeria.

39. Antai SP, Mgbomo E (1989) Distribution of hydrocarbon utilizing bacteria in the Ahoada Oil-spilled areas. Microbios letters 40: 137-143.

40. ljah UJJ, Okang CN (1993) Petroleum hydrocarbon degrading capabilities of bacteria isolated from soil. West African Journal of Biological and Applied Chemistry $38:$ 7-15.

41. Nealson KH (1997) Sediment bacteria: who's there, what are they doing, and what's new? Annu Rev Earth Planet Sci 25: 403-434. 